\title{
Applied polymers as a suitable replacement for the natural materials in the various layers of green roofs and their characteristics
}

Naser Valipour Motlagh ( $\nabla$ n.valipour.m@birjand.ac.ir )

University of Birjand https://orcid.org/0000-0002-2695-4019

\section{Zahra Arabpoor}

USB: University of Sistan and Baluchestan

Mahdiye Soltanpourgazar

Ferdowsi University of Mashhad Faculty of Engineering

\section{Research Article}

Keywords: Green roof, Polymers, Recycled polymers, Water retention additives

Posted Date: November 30th, 2021

DOI: https://doi.org/10.21203/rs.3.rs-1088617/v1

License: (c) (i) This work is licensed under a Creative Commons Attribution 4.0 International License.

Read Full License 


\section{Abstract}

Green roof is an environment-friendly structure developed globally as a result of increasing urbanization. In this review paper we first tried to collect classification, structure and materials of green roofs. Increasing water availability of substrate using water retention additives is also collected and studied in this paper. Accordingly, different materials are applied in green roofs, among which polymers have attracted a lot of attention. Polymer materials are widely used in different layers of green roofs due to their characteristics like light weight, which is an important concern about green roofs. So, in the next step, we gathered different polymeric materials that are used in different layers of green roof or can be used in this structure. For example, low density polyethylene (LDPE) or polyethylene (PP) material use as physical barriers. Therefore, this article provides an opportunity to review and compare different polymeric materials that have been studied in different articles in various layers.

\section{Introduction}

With the establishment of urbanization, green roofs also started to increase. The Green roof system is an important technology that works through the installation of plants on the roofs and helps decrease environmental problems in urban areas. Although the effects of this technology may highly depend on the location and design, it is still well known that green roofs have an important impact on the environment by reducing stormwater runoff, diminution of urban heat islands, preservation of energy, improvement of building thermal and environmental efficiency (Molineux, Fentiman et al. 2009, Coma, Pérez et al. 2014, Santamouris 2014, Zhang, Miao et al. 2015, Eksi and Rowe 2016, Sahnoune and Benhassine 2017). Moreover, green roofs bring other good results, such as reducing noise, air quality improvement and can be an ecological habitat (Renterghem and Botteldooren 2011, Rowe 2011, Renterghem, Despriet et al. 2014, Riza, Linos et al. 2015).

Although Green roofs have several advantages, studies show that their environmental benefits always depend on the materials used in the roof structure. There are several choices in the materials used in the green roof structure. A green roof may have some of the following layers: waterproofing membrane, insulation layer, root barrier, protection layer, drainage element, filter, water retention layer, growing medium, and plants. Because of various choices for applying materials in different layers, namely the growing substrate, drainage layer, plant composition and also the thickness of layers, green roof systems cannot be designed in a unique way. Diverse designs, and components can potentially be effective on the capability of green roofs to provide multiple benefits. So the use of different materials like polymers can be investigated for better performance of green roofs. (Berndtsson 2010, Tan, Tan et al. 2017).

There are limits in designing green roofs and their material construction, including the slope of the roof, exposure, weather conditions in the local area, and availability of material resources. Furthermore, there is a growing concern about the selection of more eco-friendly layers; therefore, exact evaluation of selections for various layers and their possible impact on the environment is required (Bozorg Chenani, Lehvävirta et al. 2015).Polypropylene and polyethylene can be used in the structure of green roofs 
because of their light and durable characteristics to required green roofs weight limitation. Reducing the weight of green roofs is needed for easy installation in existing buildings and to prevent the high use of expensive building materials in the construction of new buildings. Decreasing the thickness and weight of roofs are the major incentives for using polymers in the structure of green roofs. Keeping environmental benefits at a lower cost and easier maintenance is another result of using polymers (Bianchini and Hewage 2012). "The major purpose of this review paper is introducing green roofs, their classification, and features of the layers and review the polymers used in different layers. In this article also discusses some general facts about the use of different types of polymers in each layer of the green roofs."

\section{Classification And Materials Of Green Roofs}

Due to the aims and specifications, green roofs can be categorized into two main types: intensive roofs and extensive roofs. Intensive roofs require a layer of soil, skillful worker, persistent irrigation and maintenance. Extensive roofs contain a relatively thick soil layer, vegetated sedums, and moss; they benefit from self-sustainability and need the least maintenance. The combination of extensive and intensive green roofs creates another type of green roof, namely "semi- intensive" (Bianchini and Hewage 2012).

In fact, more sustainable and eco-friendly buildings were designed by the most productive solution known as green roofs. The plan of green roof construction is based on regular materials such as PP or polyester (PET) geotextiles covers, polyethylene or polystyrene panels, expanded clay, natural puzolana, and bitumen or PVC membranes (Pérez, Vila et al. 2012). According to the various kinds of green roofs, the weather conditions like temperature, wind and solar irradiance as well as roof structure, drainage material, and material form can vary. Polyethylene and polypropylene, due to their lightness and thinness, are preferred in the construction of extensive green roofs. Physical barriers are made up of low-density LDPE or PP materials. A thin and light filter layer is achieved using polymeric fibers or polyolefines. The water retention layer placed above the filter layer is a cover made of mineral wool or polymeric fibers. The natural growing medium is, in fact, typical soil (Bianchini and Hewage 2012).

\section{Applied Polymers In Green Roof}

Polymers are used in various industrial applications owing to their numerous favorable characteristics such as diversity, lightness, durability, corrosion resistance, insulation volume, low cost, and other appropriate abilities. Lower layers of green roofs tolerate heavier loads and they are exposed to high tensions. Furthermore, the water retention and drainage layer might be damaged by plant roots of the upper layers. So, in these layers it is necessary to apply the materials that have high tensile strength and fracture resistance such as polymers (Bianchini and Hewage 2012). To withstand extreme conditions of rooftop like storm water, heavy wind and rain and weight limitations, durable polymeric materials must be applied to build different parts of modern green roofs (Vijayaraghavan 2016). Generally, green roof systems consist of waterproofing membrane, insulation layer, root barrier, protection layer, drainage element, filter, water retention layer, growing medium, and vegetation (Fig. 1). In the following sections, we 
review the applied polymers which can be used in different layers of green roofs. Table (1) shows construction materials used in each layer of green roofs. 
Table 1

Applied construction materials in each layer of green roofs.

\section{Type of roof Conventional Green roof roof}

Roof layers

$\begin{array}{lll}\begin{array}{l}\text { Structural } \\ \text { support part }\end{array} & \text { Steel joist }^{\text {a }} & \text { Steel joist }^{\text {a }} \\ \begin{array}{l}\text { Decking and } \\ \text { Physical } \\ \text { barrier }\end{array} & \begin{array}{l}\text { Metal roof } \\ \text { deck }^{\text {a }}\end{array} & \text { Metal roof deck }{ }^{\text {a; }} \text { LDPE } \text { LPP }^{\text {b }} \text {; }\end{array}$

Insulation

$85 \mathrm{~mm}$

Polystyrene $^{\text {a }}$

$85 \mathrm{~mm}$ Polystyrene ${ }^{a}$

\begin{tabular}{|c|c|c|}
\hline Underlayment & $\begin{array}{l}12.5 \mathrm{~mm} \\
\text { fiber board a }\end{array}$ & $12.5 \mathrm{~mm}$ fiber board ${ }^{a}$ \\
\hline
\end{tabular}

Waterproofing 3-Ply SBS Stress Ply EUV a

membrane roofing ${ }^{\text {a }}$

Root barrier None low-density polyethylene (LDPE) or polypropylene (PP) b;

geotextiles polypropylene or polyester membranes ${ }^{\mathrm{C}}$; non-woven

polypropylene ${ }^{d}$; synthetic rubber or low-density polyethylene (LDPE) or PVC ${ }^{d}$;

Drainage None

layer

HDPE filter drain ${ }^{\text {a; }}$ recycled polypropylene ${ }^{\text {b; }}$; polyethylene or polystyrene ${ }^{\mathrm{c}, \mathrm{e}}$; high impact polystyrene (HIPS) ${ }^{\text {b}}$; semi-rigid polymeric e; non-wettable polyaramid (NPA) and wettable polyaramid (PA) f; Polyester (PET) and low-melting-point (LMPET) fibers 9 ;

a(Santamouris 2014), ${ }^{b}$ (Bianchini and Hewage 2012, Bozorg Chenani, Lehvävirta et al. 2015), ${ }^{c}($ Pérez, Vila et al. 2012), ${ }^{d}$ (Bozorg Chenani, Lehvävirta et al. 2015), ${ }^{e}\left(\right.$ Farshad and Flüeler 2004), ${ }_{1}^{f}($ Chang, Ji et al. 2017), ${ }^{\mathrm{g}}\left(\mathrm{Li}, \mathrm{Hsieh}\right.$ et al. 2016), ${ }^{\mathrm{h}}$ (Yang, Tong et al. 2013), ${ }_{,}^{\mathrm{i}}\left(\right.$ Lee, Lee et al. 2001) ${ }_{1}^{\mathrm{j}}($ Nicotera, Enotiadis et al. 2011), ${ }^{\mathrm{k}}\left(\right.$ Farrell, Ang et al. 2013), ${ }^{\prime}\left(\right.$ Savi, Marin et al. 2014), ${ }^{\mathrm{m}}\left(\right.$ Sutton 2008), ${ }^{\mathrm{n}}(\mathrm{Cao}$, Farrell et al. 2014), ${ }^{\circ}$ (Hong, Ham et al. 2016), ${ }^{\mathrm{P}}$ (Bülichen, Kainz et al. 2012), ${ }^{\mathrm{q}}$ (Bozorg Chenani, Lehvävirta et al. 2015), ${ }^{\mathrm{r}}\left(\right.$ Wong and Jim 2014, Cipolla, Ferroni et al. 2017), ${ }^{\mathrm{S}}$ (Nagase and Dunnett 2011) 


\begin{tabular}{|c|c|c|}
\hline Type of roof & $\begin{array}{l}\text { Conventional } \\
\text { roof }\end{array}$ & Green roof \\
\hline \multirow[t]{3}{*}{$\begin{array}{l}\text { Water } \\
\text { retention }\end{array}$} & None & 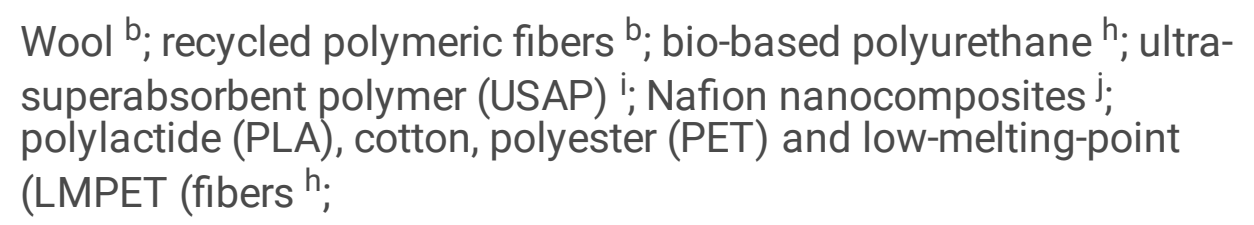 \\
\hline & & Water retention additive: \\
\hline & & $\begin{array}{l}\text { Hydrogels }{ }^{k, l} \text {; silicate }{ }^{m} \text {; hydro-absorbent polymer gel (Horta- } \\
\text { SorbTM) }{ }^{m} \text {; biochar }{ }^{n} \text {; sodium polyacrylate superabsorbent polymer } \\
\left(\text { SAP) }{ }^{\circ} \text {; methyl hydroxyethyl cellulose )MHEC) }{ }^{p} \text {; }\right.\end{array}$ \\
\hline Filter fabric & None & $\begin{array}{l}\text { HDPE filter drain }{ }^{\text {a; }} \text {; polyolefines }{ }^{\text {b; }} \text {; polypropylene; polyester } \\
\text { geotextiles; recycled polypropylene }{ }^{\text {b; }} \text { geotextile fabric } q \text {; non-woven } \\
\text { geotextile }{ }^{\text {; }}\end{array}$ \\
\hline Soil medium & None & Clay; \\
\hline Substrate & None & $\begin{array}{l}\text { Crushed concrete, mingled, Expanded slate, expanded shale, } \\
\text { expanded clay, baked clay, volcanic pumice, scoriae, sand, crushed } \\
\text { clay roofing tiles and crushed brick s; }\end{array}$ \\
\hline $\begin{array}{l}\text { Membrane } \\
\text { Protection }\end{array}$ & Stone $^{a}$ & Vegetation $^{a}$ \\
\hline \multicolumn{3}{|c|}{ 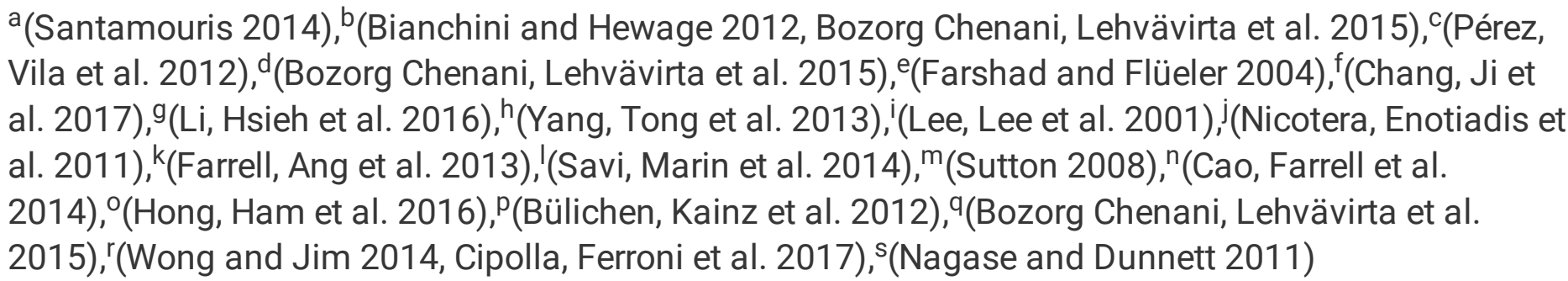 } \\
\hline
\end{tabular}

\section{Polymers in Water Retention Layer}

Often, green roofs are exploited to diminish the effect of urban heat islands (UHI) as well as storm water consequences. The water retention layer helps to retain humidity in warm and dry climates that is useful for sufficient plant growth (Tan, Tan et al. 2017). The main function of this layer is to control runoff by holding water and maintain the moisture of the growing medium layer. The retention content relies on the type of green roof, plants, building roof structure, climate, and former impregnation. The first limitation of material selection and width of water retention layer is the roofing structure. In addition to the contribution of this layer to water preservation and thermal administration, it could provide the demanded nutrients and water, which is vital for their biological performance. Besides, the layer supplies enough place for plant roots to fix and fortify, so they tolerate wind force and other harsh climates on the roof upsides. 
The light green roofs need lower water retention content. This layer can have the same structure as the drainage layer; in which the cups open upwards to retain water, while for only draining objects the cups will be open downward (Bozorg Chenani, Lehvävirta et al. 2015). Despite the other layers, the water retention layer that is located on top of the filter layer is a substrate built up of mineral wool or polymeric fibers. Moreover, this layer, in many cases, is constructed of $100 \%$ recycled polymeric fibers (Bianchini and Hewage 2012).

Materials applied in green roofs have potential environmental impacts like abiotic consumption, acidification potential, eutrophication, global warming potential, Ozone layer depletion, freshwater aquatic eco-toxicity, marine aquatic eco-toxicity, terrestrial eco-toxicity, photochemical oxidation, and human toxicity. The most impact is created by the water retention/drainage layer which is made up of rock wool. Compared with other components, recycled materials (produced from waste or recycled textile) have a less environmental impact than virginal matters (Bozorg Chenani, Lehvävirta et al. 2015).

Yang et al. synthesized biobased polyurethane using liquefied corn stover, isocyanate, and diethylenetriamine. The synthesized polyurethane as a coating material can control nitrogen $(M)$ releasing from polymer-coated urea. This new superabsorbent composite was also formularised from chicken feather protein (CFP), acrylic acid, and $N$, N-ethylenebisacrylamide and applied as an external coating matter for water preservation. They investigated $N$ release feature and water preservation ability of the double-layer polymer coated urea (DPCU) utilized in both water and soil. The polymer-coated urea (PCU) enhanced water preservation capacity and also controlled releasing rates of nutrients for more than 3 months. The use of PCU and DPCU fertilizers show decrease $N$ leaching loss from sweet corn soil-plant systems that are ordinarily used as a traditional urea fertilizer. Soil and plant evaluation features within the soil-plant system indicated that DPCU utilization efficiently decreased $N$ leaching loss, enhanced total Nuse performance, and enhanced soil water preserving ability (Yang, Tong et al. 2013). Lee et al. evaluated the effects of ultra-super absorbent polymer (USAP), a sodium-type polymer made up of $\mathrm{NaOH}$ hydrolysis after the acrylamide auto-polymerization, on the soil moisture capacity and Chinese cabbage growth. They reported that the USAP enhanced the soil water preserving capability by $4.7-6.9 \%$ on the fifth day of irrigation, and promoted the yield of Chinese cabbage by $9 \%$ (Lee, Lee et al. 2001).

The new organomodified clays were produced by Enotiadis et al. at high temperatures for better performance to retain water in polymer electrolyte membranes, and it investigated as fillers to form hybrid Nafion nanocomposites. According the study, Laponite and montmorillonite (smectite clays) having various structural factors, were charged with different cationic organic molecules. There are various hydrophilic functional groups $\left(-\mathrm{NH}_{2},-\mathrm{OH},-\mathrm{SO}_{3} \mathrm{H}\right)$ and are bounded by internalization of the solution to Nafion polymer. Its behavior at temperatures above $100^{\circ} \mathrm{C}$ is the most important property. In other words, these nanocomposites could preserve a small amount of "still mobile" water for a few hours without any additional humidity, which proposed that a notable proton conductivity can be provided by electrolytic membranes in high thermal conditions (Nicotera, Enotiadis et al. 2011). Thus, the aforementioned polymer can be used as a water retention layer.

\section{Water Retention Additives}


The main stage of planting green roofs is moisture development. Water availability of substrate can be increased by water retention additives resulting in more significant growth and survival of the plants, and give more choices for plant species that are appropriate for green roofs. Also, water holding capacity $(\mathrm{WHC})$ can increase by using water retention additives without remarkably raising the weight of the green roof layer (Farrell, Ang et al. 2013).

\section{Hydro-Absorbent Polymer Gels}

In the last decade, the gardening industry has investigated several plant medium adjustments such as hydro-absorbent polymer gels for reducing plant moisture tensions, particularly for plant growth in the limited root environment. Mentioned gels can be used on green roof farms. However, more research needs to be done on the power of absorbent gels to provide environmental moisture to the green roof. The hydrophilic polymer gel, such as those used in the Hydrotech Garden roof system, obviates the required water for the roots and can eliminate the need for structural water storage. These findings have led to a typical green roof that can be easily installed at a lower cost and potentially provide water access for the sloping green roof (Sutton 2008). Furthermore, hydrogels as superabsorbent polymers consist of an insoluble polyacrylamide gel with cross-linked crystalline forms, which could absorb water and store it up to 500 times of their weight (Farrell, Ang et al. 2013). In the other words, hydrogels are the polymer networks that catch great amounts of water and preserve it. Hydrogel structure is created by the hydration of hydrophilic groups existing in the polymeric network in an aquatic medium (Akhtar, Hanif et al. 2016). In fact, in polymer networks, hydrophilic chain segments are able to interact strongly with water, increasing the material volume extension and then forming the hydrogel. Depending on climate conditions, in reversible hydration of polymer chain segments, the smart hydrogels can shrink/swell and therefore adjust their requested volume. In so far, sol-gel transmission and swelling/shrinking performance of smart hydrogels have attracted widespread attention and these superabsorbent polymers investigated as water retention additives in green roofs (Löwenberg, Balk et al. 2017).

\section{Silicate Granules and Hydrogel}

Farrell et al. determined the impact of two various water retention additives (silicate granules and hydrogel) on layer water holding capacity (WHC), plant available water (PAW), days left until plant fading and growth of winter wheat (Triticum aestivum L.) and white lupin (Lupinus albus L.) grown in green roof layers. The usefulness of water retention additives, especially polyacrylamide hydrophilic polymer or hydrogels, to enhance plant growth and PAW, regardless of the kind of plant species, depends on the properties of the substrates and additives. The result of water retention additives on PAW varies depending on the substrates and plant species. The particle size of the substrate affects the impact of hydrogel on WHC. For these two substrates studies, any impact of water retention additives was found on $\mathrm{pH}$ or salinity (EC1: 5). Generally, it is thought that hydration of hydrogels due to the swelling process results in increased media penetration and reduced bulk density (Farrell, Ang et al. 2013).

Savi et al. evaluated the effects of modified polymeric hydrogel on the water holding capacity of a green roof layer, water estimation, and growth of Salvia officinalis. The experimental records indicated that 
modification of polymeric hydrogel (cross-linked polyacrylic acid-potassium salt, STOCKSORB 660 medium, Evonik Industries) during the green roof establishment phase increases plant water supply. The water absorption capacity for above-mentioned polymer hydrogel was up to 115 times its weight, demonstrating the potential effects of soil conditions. It was observed that by adding $0.3 \%$ and $0.6 \%$ $(w / w)$ hydrogel, a significant increase $(P<0.001)$ in the water amount of substrate at saturation by $46 \%$ and $117 \%$, was achieved, respectively. It has also increased the water availability to plants by $+45 \%$ and $+131 \%$ for the 0.3 and $0.6 \%$ mixture, respectively. However, after five months, water holding capacity of the substrate-hydrogel mixtures greatly decreased in experimental module deployment. It's assumed that the process of washout is responsible for the reduction of the water holding capacity of the substratehydrogel mixtures. This experience may suggest that by increasing the concentration of hydrogel in green roof layer, during establishment phase, more content of available water will be provided over a longer period. Furthermore, studies indicated that using hydrogel can reduce root membrane leakage of Quercus rubra seedlings by $31 \%$ after exposure to drying. The results showed that even small volumes of hydrogels mixed with green roof substrates are substantially effective to enhance the amount of water availability of the plants. Polymer hydrogel modification promoted water supplying of plants and enhanced their efficiency in green roof systems due to drought (Savi, Marin et al. 2014).

Sutton found that coarse-sized hydrophilic polymer gels (Horta-SorbTM) provide rapid internal drainage while providing the root demanded water, as well. The prairie slurry mixed with the Horta-Sorb induced a higher growth rate than the gel alone. This is probably due to the enhanced water and nutrient absorption by the mycorrhizae-rootlet (Sutton 2008).

\section{Biochar}

The carbon-rich product of high-temperature ignition (pyrolysis) of biomass is biochar, which has a different biomass source than residues of agriculture and forestry harvest wastes of urban green and manufacturing. Although, it has an organic origin, biochar is resistant to decomposition and stays intact, because of high aromatization of its carbon structure. Biochar has been applied as a soil modifier in agriculture and horticulture, which improves soil features and consequently increases plant growth range from $2-20 \%$. These modifications enhanced the water holding capacity of the soil, availability of nutrients, capacity of cation-exchange and microbial biomass. An effective method to enhancing the water holding capacity of the substrate and improving the available water of the plant of the bed is applying biochar in the substrate, which also increases storm water retention without adding weight load to the substrate. Cao et al. assessed the impacts of a kind of green waste biochar $(0,10,20,30$ and $40 \%$, $\mathrm{v} / \mathrm{v}$ ) attached two scoria-based substrates (with or without added organic matter) on WHC, bulk density, PAW and the number of days required to reach the permanent wilting point (PWP). By adding more biochar, WHC increases substantially. Under experimental conditions of this study, biochar has appeared very efficient in increasing WHC, as well as PAW, in substrates of green roofs, which postpone the stage of permanent wilting up to 2 days. The strengthening of WHC and PAW has been associated with reduced saturated bulk density, make green roofs layer lighter and make plant water supply better, making the selection of a wide range of plants possible and allowing for plant diversity (Cao, Farrell et al. 2014). 
Hong et al. evaluated sodium polyacrylate superabsorbent polymer (SAP) and Micrococcaceae HW-2 as potential plant-growth-promoting agents on rooftops of buildings under intermittent moisture conditions. In this research, they used the High-molecular-weight polymers (sodium- and potassium-type polyacrylates) with a certain ability to absorb moisture, retain water and plant-growth-promoting rhizobacteria (PGPR). The moisture absorbency and retention ability of polymer were investigated at 30 ${ }^{\circ} \mathrm{C}$ on a rooftop, respectively; the polymer illustrated a water retention potential of 11,110 times after 480 $\mathrm{h}$ and 100 times after $74 \mathrm{~h}$. Significant growth of root and biomass was observed, when using the $\mathrm{HW}-2$ and the sodium polyacrylate mixture for the Arundo donax (a drought-resistant plant). These SAPs can absorb water up to 100 times their weight. After water absorption, the polymer also shows the potential to retain moisture, especially it drains a small amount of water even under stress conditions. The sodium polyacrylate, applied as an aquatic polymer in this research, has a stable structure, and is also an environmentally benign polymer. According to the results of this study, using a mixture of the sodium-type polymer and HW-2 rhizobacterium is beneficial for the prosperous green roof (Hong, Ham et al. 2016).

\section{Methyl hydroxyethyl Cellulose}

Studies have shown that other materials such as methyl hydroxyethyl cellulose (MHEC) fiber can promote the performance of the water retention layer of green roofs. Water absorption of a single MHEC fiber at various relative moisture conditions $(10,50$, and $60 \%$ ) was investigated by Kainz et al.. It was found that the polymer volume swells considerably due to the absorption of water, and in green roofs, it can be applied as a water retention additive (Bülichen, Kainz et al. 2012).

\section{Polymers in Filter Layer}

If the filter layer has a distinct drainage layer, it usually located up of the drainage layer and under the substrate (Bozorg Chenani, Lehvävirta et al. 2015). To prevent fine particles from leaching off the roof, the filter layer should keep the substrate from crossing the drainage layer. Additionally, it keeps the uniformity of the growing medium and plant. This layer only allows water to pass through and not the fine particles of the substrate, which prevents blockage of drainage cavities. In general, filter layers are made up of $40 \%$ recycled PP, but usually, PP or PET geotextiles membranes have been exploited.

Polymeric fibers or polyolefins are applied to the construction of thin and light filter layers as well (Pérez, Vila et al. 2012). Geotextile fabrics are commonly applied on green roofs. These filter fabrics are expected to have high tensile strength to tolerate the high load. Furthermore, its fine small holes cause the water to penetrate the correct path easily, but prevent fine particles from penetrating the drainage layer. The filter fabrics for plants that have soft and short roots, act as a root-barrier membrane. The geotextile fabric is constructed of PE geotextile. The filter layer of non-woven PP with different weights has the minimum potential impact among the green roof layers. Comparison of the layers displays that a lighter filter layer has less impact (such as Abiotic depletion, Acidification, Eutrophication, Global Warming potential, Ozone layer depletion, Freshwater aquatic eco-toxicity, Marine aquatic eco-toxicity, Terrestrial eco-toxicity, 
Photochemical oxidation, and Human toxicity) than a heavier type (Bozorg Chenani, Lehvävirta et al. 2015).

Wong and Jim demonstrated that non-woven geotextile filter fabric absorbs about $1.5 \mathrm{~L}$ of water $/ \mathrm{m}^{2}$. This feature also improves the total water retention capacity of green roofs. They support the green roof operations as a source-control buffer too, that adjusts the depletion from the roof to the drainage system. The ability of the layer to detain water can be recovered over a relatively short period, as opposed to the earlier belief that it will rapidly discharge after saturation. This ability is a positive point for the use of extensive green roofs in areas with severe rainfall (Wong and Jim 2014). Licht and Lundholm specified that non-woven polymer derived from fabric can efficiently control moisture inside the substrate layers, which assisted in growing local herblike plants (Licht and Lundholm 2006). Vijayaraghavan investigated different local herblike species based on filter fabric thickness and found that thicker fabric green roofs maintain over $300 \%$ more rainfall than the green roofs without the fabric (Vijayaraghavan 2016)

\section{Polymers in Drainage Layer}

This layer prevents the water from collecting in the membrane and protects the root barrier layer. Extra water collection in root barrier persuades the roots of plants to grow. This would be detrimental to the root barriers and structure. Additional weight caused by excess water affects the required structural design of the roof; therefore, proper drainage is necessary to support the structural capacity of the roof structure. The intact water isolation membrane without any perforations is needed to perform the isolation function of lower layers. In this case, the water should be constantly discharged. The main elements of the drainage system are draining plates and water isolation membrane. Besides, drainage channels are responsible for water transport (Farshad and Flüeler 2004). According to the selected green roof system, climates, and roofing structure, the material of drainage and its shapes can vary. The weight limitation makes some polymers as light and thin materials more desirable for the construction of an extensive green roof. The prominent features such as easy transfer (in roll form) and installation, stability, durability, and cost-effective production, get manufacturers to use polymers instead of other materials. Generally, one or both sides of geotextile are polymerized to prevent blockage of drainage due to the capture of particles. The thickness of the drainage layer varies from $1.0 \mathrm{~cm}$ to $1.5 \mathrm{~cm}$ in different green roof systems. The drainage boards could enhance the building's physical characteristics of green roofs (Bianchini and Hewage 2012, Scharf and Zluwa 2017). Usually, drainage is built up of $40 \%$ recycled polypropylene. Bianchini and Hewage remarked that, commonly, recycled PP makes around $40 \%$ of the drainage and filter layer and almost $100 \%$ of the retention layer (Bianchini and Hewage 2012).

Currently, two main types of drainage layers are: 1) Nodular panels of polyethylene or polystyrene, allowing extra water to drain and provide adequate ventilation. 2) Layer produced by porous stone materials with water storage capacity, e.g., natural puzolana, expanded clay or shale, and pumice (Pérez, Vila et al. 2012).HIPS which are usually made of recycled materials, are known to have lower negative effects than intact materials. Besides, some of the HIPS with their egg-shell forms can both retain water and drain to the green roof. Their working mechanism is based on the filling of open upward cups and their overflow to the drainage ground. (Bozorg Chenani, Lehvävirta et al. 2015). 
Liu and Minor's studied two extensive green roof systems with the same principle structure and different materials and designs, in Toronto. The design that included polystyrene drainage panels and a geotextile filter (design S) induced higher insulation than the design that made up of composite polymeric drainage and a filter and a root-anchoring mat (design $S$ ). The higher insulation value of the $S$ plan proves its efficiency in reducing winter heat loss. Besides, when the winter freezing begins, the insulation value goes down for the growing medium; but the polystyrene drainage panel in design $S$ enhanced the insulation and energy efficiency of the system in this season (Liu and Minor 2005). Chang et al. have experimentally evaluated the effect of a drainage layer on the saturation of industrial cylindrical filters. The drainage layer was constructed with wettable (PA) or non-wettable polyaramid (NPA) with different average pore sizes. According to experimental results, in the absence of a drainage layer, the filter began to drain in the formation stage of liquid film, which is accompanied by a significant increase in liquid flow resistance and increases saturation. By setting up a non-wettable drainage layer, a liquid film adjustment step was added to the filtration process. Drainage significantly increased the saturation of the coalescing layer until the pressure drop was constant again (Chang, Ji et al. 2017). Hsieh et al. evaluated 4 networks were fabricated with different ratios of PLA, cotton, PET, and LMPET fibers and named as A (0/0/70/30), B (5/5/60/30), C (10/10/50/30), and D (15/15/40/30). Among these four types, cotton and PLA fibers have the ability to absorb moisture and are bio-degradable, PET fibers have the ability of absorbing moisture from the air and are crimped, and LMPET fibers are exploited as thermal bonding materials. The investigations showed that the lowest ratio of moisture value was related to fabric A. Moreover, it had the highest water preservation rate. Moisture content ratio and rate of water preservation for other fabrics $(B$, $C$, and $D$ ) were higher than fabric $A$. The fabrics $B$ and $C$ improved hygroscopic properties. Thus, fabric $A$ could be used as a drainage layer. Furthermore, fabric $D$ that was constituted of a greater amount of PLA and cotton was suitable for applications as a water preservation layer ( $\mathrm{Li}, \mathrm{Hsieh}$ et al. 2016).

\section{Polymers in Root Barrier and Other Layers}

The first layer after roof assembly is the root barrier in green roofs, which made up of traditional materials i.e. concrete. Many researchers have proposed that root barriers are a potential solution to prevent collisions between the roots of plants and roofing infrastructure. Root barriers are a physical or chemical hindrance predestinated to restraint root growth to determined areas away from infrastructure. Three main classes of root barrier are: traps, inhibitors, and deflectors (Sahnoune and Benhassine 2017). The most important function of this layer is providing a water-resistant membrane and one of the most significant goals of the designing procedure of green roof systems is to prevent roofing leakage. A lightweight layer of LDPE or PP polymers used above the roof structure is the physical barrier. Chemical barriers apply toxins such as products based on copper to prevent root penetration (Bianchini and Hewage 2012). By the way, the demand of using new waterproof membranes that promote the root barrier performance, is still necessary. The resistance of membranes against the penetration of water is related to its hydrophobic feature and pore size. Achieving complete resistance to liquid penetration in membranes is highly challenging ( $\mathrm{Li}$, Zhu et al. 2015). Generally, geotextiles PP or PET membranes are applied in the protective layer. It enables mechanical conservation of the underlying layers, particularly for the waterproofing layer. In fact, these layers (root barrier and waterproofing) preserve the buildings

Page 12/19 
against water and root penetration. Bitumen or PVC membranes, boosted with PET, fiberglass, plastics, and mineral granules, are also applied to the manufacture of root barrier and waterproofing layers. Some of them are made up of synthetic rubber or polyethylene (Pérez, Vila et al. 2012).

Bozorg Chenani et al. have proposed alternative materials for the construction of green roofs that have a high environmental impact, to obtain maximum advantages with desired performance as environmentally friendly green roofs. According to this study, it seems that developed simple green roofs do not require several sophisticated materials. During installation, geotextiles, or fabric of non-woven polypropylene, are sufficient options in protecting the membrane. This fabric is made available through the needle-felting method and in different thicknesses. Among the physical root barrier layers of synthetic rubber or LDPE or PVC with different thicknesses and weights, it was found that the lowest impact of the protection layers is related to the LDPE root barrier (Bozorg Chenani, Lehvävirta et al. 2015).

Zhao et al. applied green roof structures made of one plant and one substrate layer, two PP layers, one thick foam board for protection and a PVC waterproof layer. They concluded that the main role was related to insulation parameters. The insulation decreased the variation in substrate heat fluidities in various green roof structures, and limited the influence of the substrates and the selection of plant species. (Zhao, Tabares-Velasco et al. 2014). Mazzotta et al. provided a green waterproof membrane to protect concrete decks. The proposed waterproofing membrane is made up of a mat of recycled rubber embedded in two layers of styrene-butadiene-styrene (SBS) -modified bitumen. This membrane enhances junction adherence, and supplies proper water-resistance to the system under various conditions. The membrane of bituminous material, or a liquid-sprayed nature, is generally made up of polyurethanes or acrylics. The rubber mat is gained from natural compounds and synthetic elastomeric ones, such as recycled tires. It seems that this membrane can be considered to supply the waterproofing characteristics of green roofs. The performances of the products were monitored and the produced membrane was compared with available products. The results indicated that the SBS-modified bitumen enhanced junction bonding, tensile strength, and elongation. Accordingly, this waterproofing system is supposed to integrate high performance and environmental sustainability (Mazzotta, Lantieri et al. 2017).

Ge et al. represented a strategy for the production of waterproof electro-spun fibrous membranes. The membranes were produced employing low surface energy materials, resulting in average hydrostatic pressure of $39.3 \mathrm{kPa}$, the tensile strength of $10 \mathrm{MPa}$, and water vapor transmission rate (WVT) of 9.2 $\mathrm{kg} \cdot \mathrm{m}^{-2} \cdot \mathrm{d}^{-1}$ (Ge, Si et al. 2013). Also, Wang et al. reported a modified polyacrylonitrile fibrous membrane with an emulsion of waterborne polyurethane (WFPU). However, the membranes had a hydrostatic pressure of $83.4 \mathrm{kPa}$ and WVT rate of $9.2 \mathrm{~kg} \cdot \mathrm{m}^{-2} \cdot \mathrm{d}^{-1}$, the modification procedure was complicated (Wang, Li et al. 2014). Li et al. have reported the production of FPU/PU/CNTs fibrous membranes with excellent waterproof features. The presence of FPU and CNTs induced excellent hydrophobic properties in the membranes. Pore structure and diameter were modified by adding CNTs. Final membranes, including $0.75 \%$ CNTs, had good waterproofness of $108 \mathrm{kPa}$, WVT of $9.2 \mathrm{~kg} \cdot \mathrm{m}^{-2} \cdot \mathrm{d}^{-1}$, and mechanical attributes of $47.6 \mathrm{kPa}$ burst strength and 12.5 Mpa tensile strength. (Li, Zhu et al. 2015). 
Also, Cataldo et al. designed a procedure for keeping pipe from root penetration or growth of the root when the pipe is located underground. The designed product contained 2,6-dinitroaniline herbicide, which is a mixture of 2,6-dinitroanililne herbicide-sobbed colloidal clay and polyurethane. It seems that their method can be examined for the root barrier layer of green roofs (Cataldo, Lipinsky et al. 2006).

\section{Modular Green Roof}

Modular green roofs have been introduced and extended to facilitate the planning and implementation of green structures. The modular green roof system is designed for roofs that are planned for easy installation and less maintenance requirements using the method of clicking on the module features. The two sidewalls, defining the module environment, as well as lower and upper end walls, are interconnected together to form this module (Korol, Shushunova et al. 2019). The recycled high-density polyethylene (HDPE) has been used in the module's material (Korol and Shushunova 2016). The modules also consist of high-strength polymeric materials, which embed water storage elements and provide some space for other required components (Vijayaraghavan 2016).

\section{Conclusion}

The studies revealed the fact that to withstand extreme conditions like stormwater, heavy wind and rain of rooftop and weight limitations, durable polymeric materials should be applied for construction of the different parts of the modern green roofs. In this article, we reviewed the applied polymers, which can be used in different layers of the green roofs, as the main material or as an additive. Light and durable materials are required due to green roofs weight limitations. Physical barriers include the layer of LDPE or PP materials which are situated on the roofing structure based on the selected green roof system and its conditions. Due to their lightness and thinness, polyethylene and polypropylene are better for the construction of extensive green roofs with weight limitations. A thin and light filter layer is achieved by polymeric fibers or polyolefin. The water retention layer placed above the filter, is a coating consisting of either polymeric fibers or mineral wool. The studies concluded that the installation of "polymer" green roofs is very useful. However, it is highly encouraged to look for new materials with the potential to replace the current polymers and improve the expected performance of green roofs. Finally, it seems that the use or reuse of discarded materials is a required step in green roof construction.

\section{Statements And Declarations}

\section{Funding}

The authors declare that no funds, grant, or other support were received during the preparation of this manuscript.

\section{Competing Interests}

The authors have no relevant financial or non-financial interests to disclose. 
Availability of data and materials

Not applicable

Code Availability

Not applicable

\section{Author Contributions}

Naser Valipour Motlagh had the idea for the article, Zahra Arabpoor and Mahdiye Soltanpourgazar performed the literature search and data analysis, Zahra Arabpoor and Mahdiye Soltanpourgazar wrote the manuscript and Naser Valipour Motlagh revised the work.

\section{Ethics approval}

Not applicable

\section{Consent for participate}

Not applicable

\section{Consent for publication}

Not applicable

\section{Acknowledgement}

Authors would like to thank Miss Reyhane Gholami for the helpful correction of the manuscript.

\section{References}

1. Akhtar MF, Hanif M, Ranjha NM (2016) Methods of synthesis of hydrogels... a review. Saudi Pharmaceutical Journal 24(5):554-559

2. Barreca F (2016) Rooftop gardening. A solution for energy saving and landscape enhancement in Mediterranean urban areas. Procedia-Social and Behavioral Sciences 223:720-725

3. Berndtsson JC (2010) "Green roof performance towards management of runoff water quantity and quality: A review". Ecol Eng 36(4):351-360

4. Bianchini F, Hewage K (2012) How "green" are the green roofs? Lifecycle analysis of green roof materials. Build Environ 48:57-65

5. Bozorg Chenani S, Lehvävirta S, Häkkinen T (2015) Life cycle assessment of layers of green roofs. J Clean Prod 90:153-162

6. Bülichen D, Kainz J, Plank J (2012) Working mechanism of methyl hydroxyethyl cellulose (MHEC) as water retention agent. Cem Concr Res 42(7):953-959 
7. Cao CT, Farrell C, Kristiansen PE, Rayner JP (2014) Biochar makes green roof substrates lighter and improves water supply to plants. Ecol Eng 71:368-374

8. Cataldo DA, Lipinsky ES, Voris PV, Beck DL, Beck R (2006) Methods and products to protect against root intrusion and plant and root growth. Google Patents

9. Chang C, Ji Z, Liu J (2017) The effect of a drainage layer on the saturation of coalescing filters in the filtration process. Chem Eng Sci 160:354-361

10. Cipolla S, Ferroni L, Maglionico M, Speranza M (2017) Green roofs: effects of hydrogel on hydrological and ecological behavior. International Symposium on Greener Cities for More Efficient Ecosystem Services in a Climate Changing World 1215

11. Coma J, Pérez G, Castell A, Solé C, Cabeza LF (2014) "Green roofs as passive system for energy savings in buildings during the cooling period: use of rubber crumbs as drainage layer". Energ Effi 7(5):841-849

12. Eksi M, Rowe DB (2016) Green roof substrates: Effect of recycled crushed porcelain and foamed glass on plant growth and water retention. Urban Forestry \& Urban Greening 20:81-88

13. Farrell C, Ang XQ, Rayner JP (2013) Water-retention additives increase plant available water in green roof substrates. Ecol Eng 52:112-118

14. Farshad M, Flüeler P (2004) Drainage behavior of two-layered water-sealing polymeric systems. Polym Test 23(1):43-49

15. Mahmud GHashemi, Ashraf M (2015) "Performance of green roofs with respect to water quality and reduction of energy consumption in tropics: A review." Renewable and Sustainable Energy Reviews 52: 669-679

16. Hong SH, Ham SY, Kim JS, Kim I-S, Lee EY (2016) Application of sodium polyacrylate and plant growth-promoting bacterium, Micrococcaceae HW-2, on the growth of plants cultivated in the rooftop. Int Biodeterior Biodegrad 113:297-303

17. Korol E, Shushunova N (2016) "Benefits of a Modular Green Roof Technology " Procedia Engineering 161:1820-1826

18. Korol E, Shushunova N, Rerikh S (2019) New green roof and green wall systems for implementation in the coverings. E3S Web of Conferences, EDP Sciences

19. Lee K, Lee D, Moon S, Kim M (2001) "Effect of Chinese Cabbage Growth and Change of Nutrient and Soil Water on Application of Super Water Absorbent Polymer". Korean J Soil Sci Fertil 34:350-357

20. Li J-H, Hsieh J-C, Lou C-W, Hsieh C-T, Pan Y-J, Hsing W-H, Lin J-H (2016) Using nonwoven fabrics as culture mediums for extensive green roofs: physical properties and cooling effect. Fibers Polym 17(7):1111-1114

21. Li Y, Zhu Z, Yu J, Ding B (2015) Carbon nanotubes enhanced fluorinated polyurethane macroporous membranes for waterproof and breathable application. ACS Appl Mater Interfaces 7(24):1353813546 
22. Licht J, Lundholm J (2006) Native Coastal Plants for Northeastern Extensive and Semi-intensive Green Roof trays: Substrates, Fabrics, and Plant Selection. Proc. of 4th North American Green Roof Conference: Greening Rooftops for Sustainable Communities, Boston, Mass

23. Liu K, Minor J (2005) "Performance evaluation of an extensive green roof." Presentation at Green Rooftops for Sustainable Communities. Washington DC 1:1-11

24. Löwenberg C, Balk M, Wischke C, Behl M, Lendlein A (2017) Shape-memory hydrogels: evolution of structural principles to enable shape switching of hydrophilic polymer networks. Acc Chem Res 50(4):723-732

25. Mazzotta F, Lantieri C, Vignali V, Simone A, Dondi G, Sangiorgi C (2017) Performance evaluation of recycled rubber waterproofing bituminous membranes for concrete bridge decks and other surfaces. Constr Build Mater 136:524-532

26. Molineux CJ, Fentiman CH, Gange AC (2009) "Characterising alternative recycled waste materials for use as green roof growing media. in the UK " Ecological Engineering 35(10):1507-1513

27. Moon HJ, An K, Han S (2014) Energy Saving Effects of Green Roof in Existing Buildings with Low Insulation Levels

28. Nagase A, Dunnett N (2011) The relationship between percentage of organic matter in substrate and plant growth in extensive green roofs. Landscape and Urban Planning 103(2):230-236

29. Nguyen TT, Ngo HH, Guo W, Wang XC, Ren N, Li G, Ding J, Liang H (2019) Implementation of a specific urban water management - Sponge City. Sci Total Environ 652:147-162

30. Nicotera I, Enotiadis A, Angjeli K, Coppola L, Ranieri GA, Gournis D (2011) "Effective improvement of water-retention in nanocomposite membranes using novel organo-modified clays as fillers for high temperature PEMFCs". J Phys Chem B 115(29):9087-9097

31. Oberndorfer E, Lundholm J, Bass B, Coffman RR, Doshi H, Dunnett N, Gaffin S, Köhler M, Liu KK, Rowe B (2007) "Green roofs as urban ecosystems: ecological structures. functions, and services " BioScience 57(10):823-833

32. Peck SW, Callaghan C, Kuhn ME, Bass B (1999) Greenbacks from green roofs: forging a new industry in Canada. CMHC

33. Pérez G, Vila A, Rincón L, Solé C, Cabeza LF (2012) Use of rubber crumbs as drainage layer in green roofs as potential energy improvement material. Appl Energy 97:347-354

34. Renterghem T, Despriet M, Botteldooren D (2014) "Experimental analysis of the noise shielding by a green roof in response to rainfall." INTERNOISE 2014 - 43rd International Congress on Noise Control Engineering. Improving the World Through Noise Control

35. Renterghem TV, Botteldooren D (2011) Sound reduction by vegetated roof tops (green roofs): a measurement campaign

36. Riza E, Linos A, Petralias A, de Martinis L, Duntas L, Linos D (2015) The effect of Greek herbal tea consumption on thyroid cancer: a case-control study. Eur J Pub Health 25(6):1001-1005

37. Rowe DB (2011) "Green roofs as a means of pollution abatement". Environ Pollut 159(8):2100-2110 
38. Sahnoune S, Benhassine N (2017) Quantifying the Impact of Green-Roofs on Urban Heat Island Mitigation. Int J Environ Sci Dev 8(2):116

39. Santamouris M (2014) Cooling the cities-a review of reflective and green roof mitigation technologies to fight heat island and improve comfort in urban environments. Sol Energy 103:682703

40. Savi T, Marin M, Boldrin D, Incerti G, Andri S, Nardini A (2014) Green roofs for a drier world: effects of hydrogel amendment on substrate and plant water status. Sci Total Environ 490:467-476

41. Scharf B, Zluwa I (2017) "Case study investigation of the building physical properties of seven different green roof systems. " Energy and Buildings

42. Springer k (2017) "Turf homes: Inside the grass-topped farmhouses that defined Iceland. " CNN style

43. Sutton RK (2008) "Media Modifications. for Native Plant Asemblages on Extensive Green Roofs."

44. Tan CL, Tan PY, Wong NH, Takasuna H, Kudo T, Takemasa Y, Lim CVJ, Chua HXV (2017) "Impact of soil and water retention characteristics on green roof thermal performance. " Energy and Buildings

45. Vijayaraghavan K (2016) Green roofs: A critical review on the role of components, benefits, limitations and trends. Renew Sustain Energy Rev 57:740-752

46. Wang J, Li Y, Tian H, Sheng J, Yu J, Ding B (2014) "Waterproof and breathable membranes of waterborne fluorinated polyurethane modified electrospun polyacrylonitrile fibers". RSC Adv 4(105):61068-61076

47. Whitfield J (2009) Seeds of an edible city architecture. Nature 459(7249):914-915

48. Wong GK, Jim C (2014) Quantitative hydrologic performance of extensive green roof under humidtropical rainfall regime. Ecol Eng 70:366-378

49. Yang Y, Tong Z, Geng Y, Li Y, Zhang M (2013) Biobased polymer composites derived from corn stover and feather meals as double-coating materials for controlled-release and water-retention urea fertilizers. J Agric Food Chem 61(34):8166-8174

50. Yao L, Chini A, Zeng R (2020) Integrating cost-benefits analysis and life cycle assessment of green roofs: a case study in Florida. Human and Ecological Risk Assessment: An International Journal 26(2):443-458

51. Zhang Q, Miao L, Wang X, Liu D, Zhu L, Zhou B, Sun J, Liu J (2015) The capacity of greening roof to reduce stormwater runoff and pollution. Landscape and Urban Planning 144:142-150

52. Zhao M, Tabares-Velasco PC, Srebric J, Komarneni S, Berghage R (2014) Effects of plant and substrate selection on thermal performance of green roofs during the summer. Build Environ 78:199-211

\section{Figures}




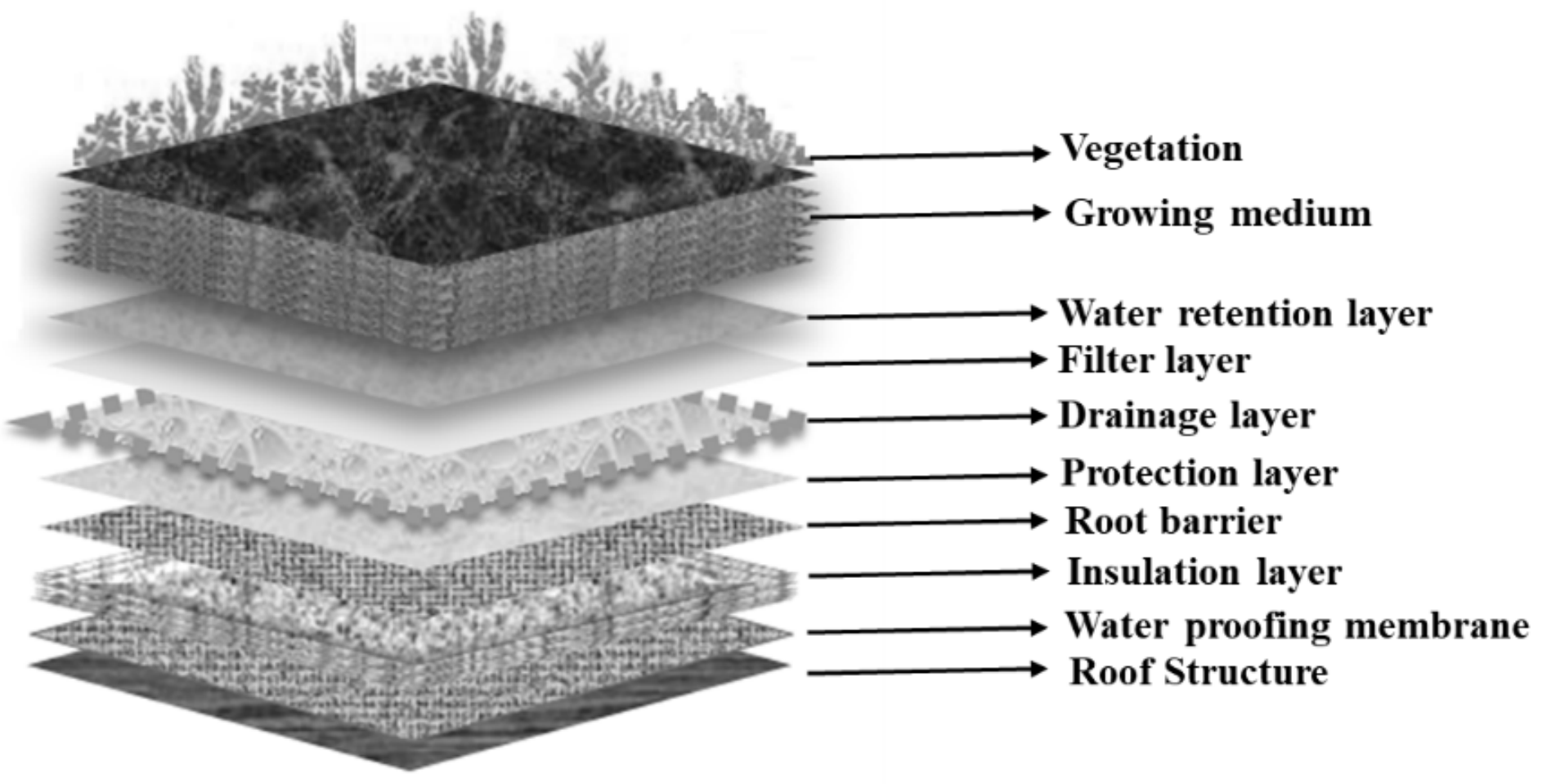

Figure 1

Different components of green roof 